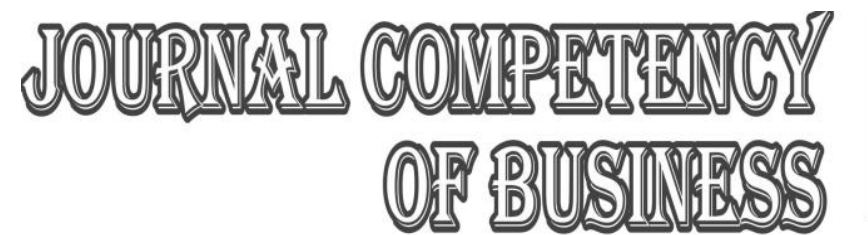

Fakultas Ekonomi, Universitas Cokroaminoto Yogyakarta

\title{
PENGEMBANGAN PRODUK ANYAMAN TAESTHIC.CO DALAM MENINGKATKAN PENJUALAN
}

\author{
Suyatmi $^{1}$, Diffa Maysca ${ }^{2}$ \\ ${ }^{1,2}$ Prodi Kewirausahaan, Fakultas Ekonomi dan Sosial, Universitas Amikom Yogyakarta \\ 11mbak_ami@amikom.ac.id
}

\begin{abstract}
ABSTRAK
Indonesia mempunyai beragam keanekaragaman budaya dan kerajinan secara turun temurun. Menjaga kelestarian seni kerajinan anyaman yang merupakan salah satu kesenian yang harus di jaga, salah satunya adalah tas anyaman plastik. Seiring berubahnya zaman menjadi modern saat ini tidak banyak yang menggunakan tas anyaman plastik karena dianggap kuno dan kurang bervariasi. Produk lokal juga banyak ditinggalkan karena di nilai tidak berkualitas dan juga tidak bervariasi. Kurangnya peminat tas anyaman plastik mengakibatkan banyak pengrajin yang kehilangan pekerjaan. Maka Taesthic.co hadir untuk membantu para pengrajin dalam memasarkan produk dan memperkenalkan produk lokal. Taesthic.co di bentuk pada bulan februari 2020 terletak di Daerah Istimewa Yogyakarta yang bertujuan untuk bekerjasama dengan memberdayakan pengrajin dan juga untuk mengembangkan produk lokal tas anyaman plastik agar dapat meningkatkan penjualan. Target penjualan dari taesthic.co adalah wanita umur 25-45 tahun. Dalam mengembangkan dan meningkatkan penjualan Taesthic.co menggunakan bisnis model canvas karena bekerja sama oleh para pengrajin anyaman plastik dari daerah Ponorogo, mengunggulkan kualitas dan keunikan dari produk anyaman, promosi yang dilakukan menggunakan website, sosial media dan juga ecommerce.
\end{abstract}

Kata kunci: Bisnis Model Canvas, Pengembangan Produk, dan Online Marketing

\begin{abstract}
Indonesia has a variety of cultural diversity and handicrafts from generation to generation. Preserving the art of woven crafts which is one of the arts that must be preserved, one of which is plastic woven bags. As times change to modern times, not many people use plastic woven bags because they are considered old-fashioned and less varied. Local products are also widely abandoned because the value is not of quality and also does not vary. The lack of interest in plastic woven bags has resulted in many craftsmen losing their jobs. So Taesthic.co is here to help craftsmen in marketing their products and introducing local products. Taesthic.co was formed in February 2020 located in the Special Region of Yogyakarta which aims to collaborate with empowering craftsmen and also to develop local products of woven plastic bags in order to increase sales. The sales target of taesthic.co is women aged 25-45 years. In developing and increasing sales, Taesthic.co uses a canvas business model because it works together with plastic woven craftsmen from the Ponorogo area, emphasizing the quality and uniqueness of woven products, promotions are carried out using websites, social media and also e-commerce
\end{abstract}

Keywords: Business Model Canvas, Product Development, and Online Marketing

E-ISSN: 2777-1156

2021. Vol 5. No 1 


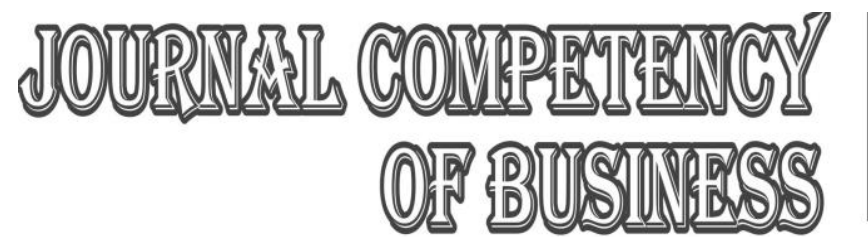

Fakultas Ekonomi, Universitas Cokroaminoto Yogyakarta

\section{PENDAHULUAN}

Taesthic.co merupakan perusahaan yang bekerjasama dengan para pengrajin tas anyaman plastic. Produk tas anyaman plastik yang diambil langsung dari tangan pengrajin tas anyaman plastik di daerah ponorogo. Produk lokal tas anyaman plastik memiliki beragam variasi model tas yang sangat modern dan menggunakan bahan plastic premium. Dapat digunakan untuk berbelanja, sehingga mengurangi penggunakan sampah plastik. Tujuan dari taesthic.co adalah menaikkan penjualan produk lokal seperti tas anyaman plastik ini dengan memberdayakan para pengrajin, melestarikan dan juga memperkenalkan produk tas anyaman plastik kepada masyarakat harga yang di perjualkan sangat terjangkau mulai dari Rp. 70.000 - Rp100.000. Target pelanggan untuk taesthic.co adalah perempuan dewasa yaitu umur 25-45 tahun. Taesthic.co masuk kedalam 3 segmen yaitu kebawah, menengah, dan atas. Taesthic.co di fokuskan pada kota Jakarta, Surabaya, Bandung, Medan, Palu, dan Denpasar.

Tabel 1. Market Size dan Market Share

\begin{tabular}{|l|l|}
\hline Pasar Sasaran & $\begin{array}{l}\text { Wanita Umur 25-45 Tahun } \\
\text { DKI Jakarta, Surabaya, Bandung, } \\
\text { Medan, Palu, Denpasar }\end{array}$ \\
\hline Market Size & 5.311 .889 \\
\hline Market Share & $1 \%$ X 5.311.889=53.118,89 \\
\hline Target Pasar & $53.118,89$ \\
\hline
\end{tabular}

Sumber: https://bps.go.id (Diakses 25 Januari 2021)

Berdasarkan data tersebut sehingga total penduduk yang berada di DKI Jakarta, Surabaya, Bandung, Medan,Palu, Denpasar sejumlah 5.311.889 jiwa yang menjadi market size dari Taesthic.co kemudian mengambil 1\% dari market size yang berjumlah 53.118,89 jiwa untuk menjadi market share. Target taesthic.co yaitu untuk dapat bisa memperluas pasar di seluruh Indonesia. Strategi bisnis untuk mengakuisisi pasar dengan cara mencari reseller dari berbagai daerah yang dimaksudkan untuk dapat memperluas pasar. Taesthic.co akan

E-ISSN: 2777-1156

2021. Vol 5. No 1 
Fakultas Ekonomi, Universitas Cokroaminoto Yogyakarta

membuat produk anyaman untuk anak-anak dan pria dengan bahan baku yang terbuat dari anyaman jerami, rotan dan rajutan.

Penelitian ini mengacu pada beberapa hasil penelitian sebelumnya yang meneliti mengenai konsep bisnis kanvas model, hasil penelitian yang dilakukan oleh Ferranti dan Anne (2020) menunjukkan hasil bahwa Bisnis Kanvas Model digunakan dalam penilaian infrastruktur hijau (green infrastructure) untuk membuat kerangka kerja yang berfokus pada (i) Change Objective, (ii) Target Audience, (iii) Key Activities, (iv) Key Resources, (v) Key Partners, (vi) Channels,(vii) Audience Message, (viii) CostStructure,and (ix) Revenue Streams. Bisnis kanvas model meningkatkan dampak alat penilaian dengan memfokuskan proses evaluasi pada tujuan untuk mengembangkan strategi bisnis. Penelitian yang dilakukan oleh Brunner dan Josef (2020) menyatakan bahwa transformasi digital merupakan tantangan utama bagi perusahaan. Namun demikian, tantangan utama ini juga merupakan peluang besar seperti pengoptimalan produksi dan proses bisnis. Bisnis Kanvas Model member pedoman dan acuan bagi perusahaan untuk mendokumentasikan model bisnis baru yang ada dan yang sedang berkembang.

Adapun permsalahan yang muncul adalah bagaimana cara meningkatkan penghasilan pengrajin tas anyaman plastic serta bagaimana pengembangan produk anyaman taesthic.co dalam meningkatkan penjualan. Berdasarkan pada permasalahan diatas maka Taesthic.co menawarkan solusi berupa memberdayakan pengrajin tas anyaman plastik untuk meningkatkan penghasilan serta menggunakan bisnis model canvas yang berguna untuk meningkatkan penjualan dan memperluas pasar dengan pemasaran online. Tujuan penulisan ini untuk bekerjasama dengan memberdayakan pengrajin anyaman di daerah Ponorogo dan juga untuk mengembangkan produk lokal tas anyaman plastik agar dapat meningkatkan penjualan di tahun 2020. Dengan menggunakan Bisnis Model Canvas dan Media pemasaran online seperti website, sosial media dan e-commercee. 
Fakultas Ekonomi, Universitas Cokroaminoto Yogyakarta

\section{KAJIAN PUSTAKA}

\section{Business Model Canvas}

Kepopuleran konsep model bisnis di mulai sejak tahun 1990 ke atas ketika internet mulai banyak membahas tentang konteks model bisnis dalam sebuah perusahaan dan bagaimana perubahan lingkungan bisnis. Konsep model bisnis digunakan sebagai cara yang umum untuk menjelaskan bagaimana perusahaan berinteraksi dengan pemasok, mitra kerja, dan pelanggan, serta untuk menggambarkan dasar pemikiran tentang bagaimana organisasi menciptakan, memberikan, dan menangkap nilai (Gunawan, 2016). Buku yang berjudul "Business Model Generation" (Osterwalder dan Pigneur, 2010) membuat suatu kerangka business model yang berbentuk kanvas dan terdiri dari sembilan kotak yang saling berkaitan. Kotak-kotak ini berisikan elemenelemen penting yang menggambarkan bagaimana organisasi menciptakan nilai dan mendapatkan manfaat dari para pelanggannya. Penjelasan kesembilan kotak tersebut menurut (Wardhanie, 2017) antara lain :

a. Customer Segments adalah masyarakat yang menggunakan jasa/produk dari organisasi dan mereka yang berkontribusi dalam memberikan penghasilan bagi organisasi. Segmentasi pelanggan juga dapat dipilah berdasarkan perilaku, umur, profesi, penghasilan dan geografi.

b. Value Propositions merupakan satu keunikan yang menentukan mengapa produk atau jasa tersebut pantas dipilih oleh pelanggan. Hal ini memberi tawaran untuk memecahkan masalah pelanggan dan semaksimal mungkin memenuhi keinginan pelanggan.

c. Channel, sebuah elemen seperti komunikasi, distribusi dan saluran penjualan yang menyatakan bagaimana cara organisasi berkomunikasi dengan pelanggan segmennya dan menyampaikan value propositionnya.

d. Customer Relationship, pembinaan hubungan dengan pelanggan, dengan tujuan untuk mendapatkan pelanggan baru dan mempertahankan pelanggan lama.

E-ISSN: 2777-1156

2021. Vol 5. No 1 
Fakultas Ekonomi, Universitas Cokroaminoto Yogyakarta

e. Revenue Streams atau aliran dana masuk yang menggambarkan bagaimana organisasi memperoleh penghasilan berupa uang dari setiap customer segments. Aliran dana inilah yang membuat sebuah perusahaan tetap hidup atau survive.

f. Key Resources menggambarkan aset-aset terpenting yang menentukan keberhasilan pengoperasian model bisnis, seperti bangunan, kendaraan, intelektual dan tenaga kerja.

g. Key Activities merupakan kegiatan utama yang menunjang keberhasilan suatu model bisnis dalam mengirimkan value propotitions-nya kepada pelanggan.

h. Key Partnership, suatu kesepakatan kerja sama bisnis yang diprakarsai secara sukarela antara dua atau lebih perusahaan untuk menyelesaikan proyek tertentu. Kerjasama ini dapat menimbulkan penghematan biaya, mengurangi resiko dan memperoleh sumber daya yang tidak dimiliki perusahaan.

i. Cost Structure menggambarkan semua biaya yang muncul sebagai akibat dioperasikannya model bisnis ini guna mewujudkan value propotitions melalui channel, key resource, key activities yang tepat dan dapat diandalkan.

Osterwalder dan Pigneur (2012) mengemukakan bahwa business model canvas merupakan sebuah template berupa grafik visual berbentuk tabel yang berisi sembilan blok bangunan yang digunakan untuk menciptakan bisnis inovatif. Kesembilan blok bangunan tersebut mencakup empat bidang utama dalam suatu bisnis yaitu pelanggan, penawaran, infrastruktur dan kelangsungan finansial. Pengembangan aplikasi visualisasi model bisnis telah dilakukan oleh Osterwalder dan Pigneur (2012) dalam bentuk kanvas model bisnis. Penggunaan kanvas model bisnis dapat memberikan gambaran mengenai model bisnis perusahaan dan hubungan yang terjadi antar-blok dengan cara yang lebih atraktif. Business Model Canvas juga membantu perusahaan untuk mengenali apa yang menjadi value proposition perusahaan, serta bagaimana membangun dan menjalankan key activities dan key resources dalam menciptakan value proposition dan mendapatkan revenue streams, memahami bagaimana produk dan jasa yang ditawarkan perusahaan dapat dikomunikasikan dengan baik kepada konsumen hingga sampai ke tangan konsumen untuk dikonsumsi. Business model canvas tidak hanya dapat

\section{E-ISSN: 2777-1156}

2021. Vol 5. No 1 


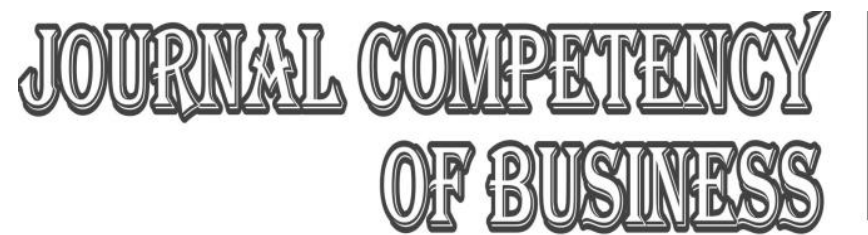

Fakultas Ekonomi, Universitas Cokroaminoto Yogyakarta

digunakan untuk memotret model bisnis perusahaan saat ini, namun juga dapat digunakan sebagai alat untuk memberikan usulan rancangan model bisnis yang baru. Penerapan business model canvas di Indonesia masih relatif baru dibandingkan dengan beberapa model manajemen strategi bisnis lainnya.

\section{METODE PENELITIAN}

Penelitian ini menggunakan metode deskriptif dengan pendekatan kualitatif, yakni menjelaskan dan menggambarkan secara mendalam tentang situasi atau proses yang diteliti (Moleong, 2012). Penelitian ini mengambil bisnis Taesthic.co. Informan kunci dalam penelitian ini adalah pemilik dan pengelola Taesthic.co. Selain itu peneliti juga mengambil data sekunder melalui media sosial. Analisis data bersifat induktif kualitatif dan hasil dari penelitian ini bertujuan untuk mencari informasi faktual yang detail mengenai gejala yang ada, mengidentifikasi masalah - masalah yang terjadi dan praktik - praktik yang sedang berlangsung dengan melakukan wawancara mendalam terhadap subyek penelitian sehingga dapat memberikan gambaran yang jelas mengenai penerapan business model canvas pada bisnis Taesthic.co.

\section{HASIL ANALISIS DAN PEMBAHASAN}

\section{Pesaing dan Produk/Jasa}

Pada saat ini pesaing Taesthic.co sudah banyak memiliki pelanggan tetap dan memiliki pasar yang stabil. Produk yang ditawarkan mempunyai banyak variasi selain bahan dasar dan juga produk. Strategi yang dilakukan Taesthic.co dalam menghadapi persaingan yaitu dengan memberikan produk yang berkualitas, potongan harga dan juga gratis syall yang dapat menarik peminat calon pelanggan. Adapun strategi lain yang digunakan yaitu memaksimalkan pemasaran di media (website, sosial media dan e-commerce). Berikut gambaran position map pada Taesthic.co

E-ISSN: 2777-1156

2021. Vol 5. No 1 
Fakultas Ekonomi, Universitas Cokroaminoto Yogyakarta

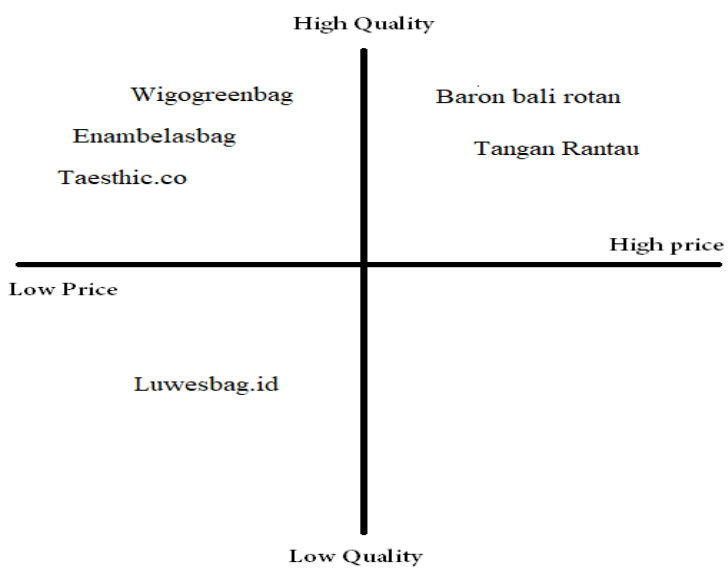

Gambar 1. Position Map

\section{Pesaing}

a. Tangan Rantau yang berlokasi di DKI Jakarta menjual produk - produk anyaman tas yang tidak hanya dari plastic jaly tetapi jerami, rajutan dan juga rotan. Media pemasaran yang digunakan melalui instagram dan shopee.

b. Wigogreenbag menjual berbagai macam tas anyaman plastic yang berlokasi di daerah Tangerang. Media pemasaran yang digunakan melalui instagram, facebook dan shopee.

c. Luwesbag.id yang berlokasi di Surabaya ini menjual produk-produk tas anyaman plastik. Media pemasaran yang digunakan yaitu shopee, website dan juga instagram.

d. Baron bali rotan menjual produk tas anyaman rotan dan berlokasi di daerah Bali. Media pemasaran yang digunakan yaitu instagram dan tokopedia

e. Enambelasbag yang belokasi di daerah magelang menjual berbagai macam tas anyaman plastik. Media pemasaran yang digunakan melalui shopee dan facebook.

\section{Keunggulan Produk/Jasa Pesaing}

a. Tangan Rantau memiliki kelebihan yaitu mengusung tema ethnic karena tidak hanya dengan menjual produk yang berbahan dasar anyaman plastic tetapi juga berbahan

E-ISSN: 2777-1156 


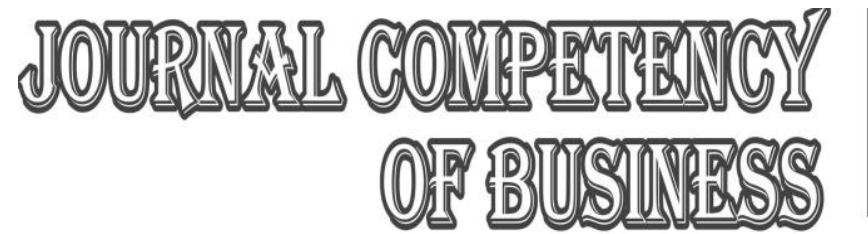

Fakultas Ekonomi, Universitas Cokroaminoto Yogyakarta

dasar jerami, rotan dan rajut. Selain terdapat berbagai macam produk riasan, tas dan sandal.

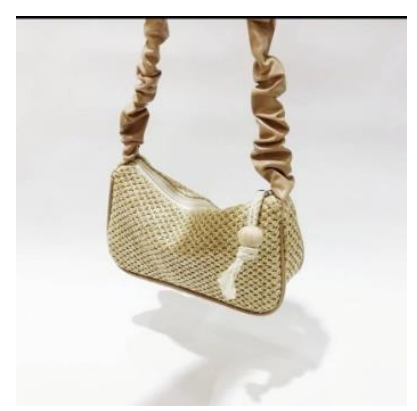

Gambar 2 Tas anyaman jerami with PU Leather

b. Wigogreenbag memiliki kelebihan yaitu mempunyai karakter di setiap tas dengan menggunakan syall yang diberikan sehingga mempunyai karakter dan elegan di setiap pemakai.

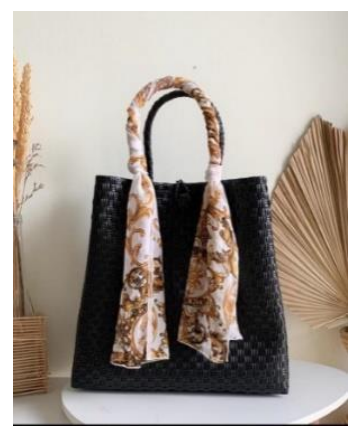

Gambar 3. Tas Anyaman Jaly with Syall ukuran M

E-ISSN: 2777-1156

2021. Vol 5. No 1 


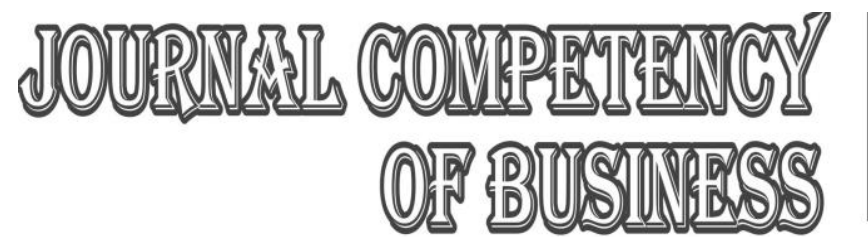

Fakultas Ekonomi, Universitas Cokroaminoto Yogyakarta

c. Luwesbag.id memiliki kelebihan pada variasi produk tas anyamannya.

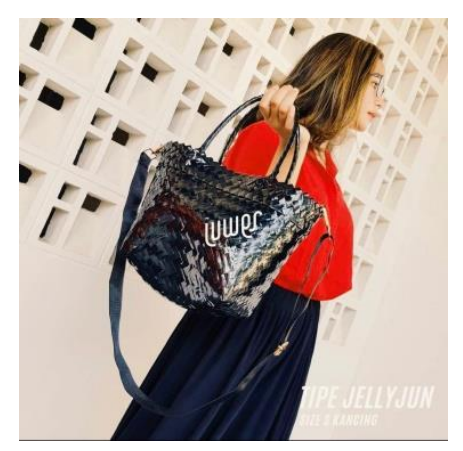

Gambar 4. Jellyjun ukuran S

d. Baron bali rotan memiliki kelebihan yaitu mempunya banyak variasi produk tidak hanya tas yang berbahan dasar rotan tetapi sandal dan juga produk tas yang terbuat dari rajut. Baron bali rotan juga memproduksi dan mendesaign produk mereka sendiri sehingga produk menjadi lebih eksklusif.

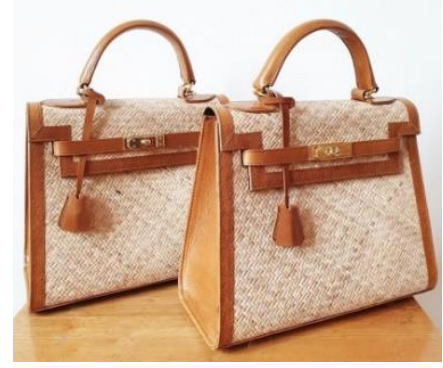

\section{Gambar 5. Kelly}

e. Enambelasbag memiliki kelebihan yaitu pada warna produk yang lebih menarik dan bernuansa muda (lembut) yang jarang dimiliki oleh pengrajin lainnya.

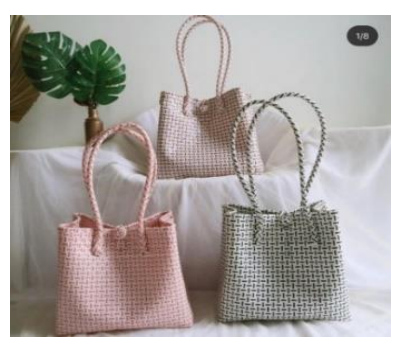

Gambar 6. Tas Anyaman Jaly ukuran S

E-ISSN: 2777-1156

2021. Vol 5. No 1 


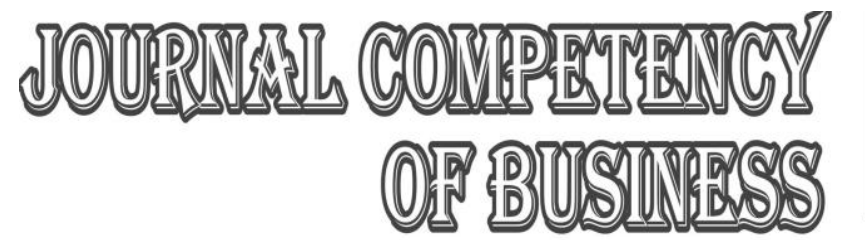

Fakultas Ekonomi, Universitas Cokroaminoto Yogyakarta

\section{Target Pelanggan}

Target pelanggan untuk taesthic.co adalah perempuan dewasa yaitu umur 25-45 tahun. Taesthic.co masuk kedalam 3 segmen yaitu kebawah, menengah, dan atas. Taesthic.co di fokuskan pada kota Jakarta, Surabaya, Bandung, Medan, Palu, dan Denpasar.

\section{Strategi Pemasaran}

Strategi pemasaran yang akan diimplementasikan dengan menggunakan analisa

4P yang meliputi:

a. Produk (Product)

Tas anyaman plastik yang diambil langsung oleh para pengrajin di daerah Ponorogo, Jawa Timur. Produk yang di tawarkan berbagai variasi mulai dari ukuran S, M dan L. Selain itu bahan yang digunakan adalah kualitas premium, sehingga tidak membuat tangan sakit jika dipakai. Warna yang ditawarkan sangat beragam.

b. Harga (Price)

Taesthic.co memberikan potongan harga untuk yang membeli $>5$ pcs dan juga untuk reseller.

Taesthic.co memberikan harga terjangkau mulai dari Rp. 70.000 - Rp.100.000 sesuai dengan kualitas, warna, dan bentuk variasi tas.

c. Strategi Promosi (Promotion)

Media online dan offline. Instagram dan Facebook : @Taesthic.co; Shopee:

Taesthic.co ; website https://taesthicco.tapao.us/ Whatsapp: 0821-4241-0006

d. Strategi Distribusi/Tempat (Place)

- Lokasi Penjualan

Jalan Wahid Hasyim Gg Mawar no 21, ngropoh, Yogyakarta.

E-ISSN: 2777-1156 
Fakultas Ekonomi, Universitas Cokroaminoto Yogyakarta

- Strategi Penjualan

Secara langsung dengan mengirimkan kepada customer dan melalui reseller

Tantangan terbesar organisasi yaitu kemampuan mendesain sebuah model bisnis yang baru dan inovatif. Target taesthic.co yaitu untuk dapat bisa memperluas pasar di seluruh Indonesia. Strategi bisnis untuk mengakuisisi pasar dengan cara mencari reseller dari berbagai daerah yang dimaksudkan untuk dapat memperluas pasar. Taesthic.co akan membuat produk anyaman untuk anak-anak dan pria dengan bahan baku yang terbuat dari anyaman jerami, rotan dan rajutan. Oleh sebab itu, peneliti melakukan penelitian ini dengan cara pengumpulan data secara observasi, wawancara dan dokumentasi untuk membuat business model dengan bantuan business model canvas yang terdiri dari 9 elemen berikut ini:

Tabel 2 Bisnis Model Canvas

\begin{tabular}{|c|c|c|c|c|}
\hline \multicolumn{2}{|c|}{ Business Model Canvas } & \multirow[b]{2}{*}{$\begin{array}{l}\text { Value } \\
\text { Propositions }\end{array}$} & \multirow[b]{2}{*}{$\begin{array}{l}\text { Customer } \\
\text { Relationships }\end{array}$} & \multirow[b]{2}{*}{ Customer Segmen } \\
\hline $\begin{array}{l}\text { Key } \\
\text { Partners }\end{array}$ & $\begin{array}{l}\text { Key } \\
\text { Activities }\end{array}$ & & & \\
\hline \multirow[t]{3}{*}{$\begin{array}{l}\begin{array}{l}\text { Pengrajin } \\
\text { anyaman } \\
\text { plastic }\end{array} \\
\text { - Reseller } \\
\text { Taesthic.co }\end{array}$} & $\begin{array}{l}\text { - } \text { Pengecekan } \\
\text { Produk dari } \\
\text { Pengrajin } \\
\text { Anyaman } \\
\text { - Kegiatan } \\
\text { Pengemasan } \\
\text { - } \text { Kegiatan } \\
\text { Pemasaran }\end{array}$ & \multirow[t]{3}{*}{ 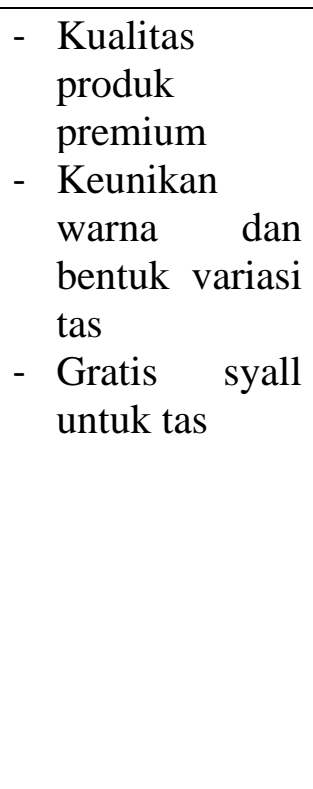 } & 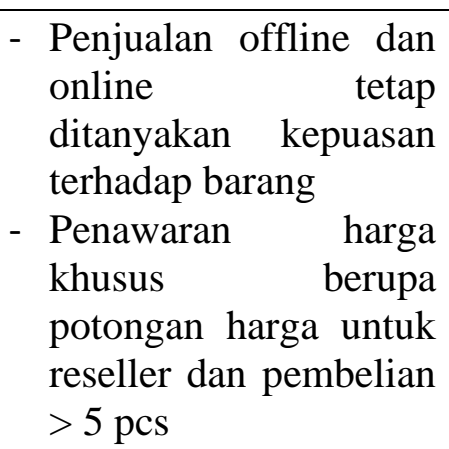 & \multirow[t]{3}{*}{$\begin{array}{l}\text { - Wanita umur } \\
\text { 25-45 Tahun } \\
\text { - Pekerja dan ibu } \\
\text { rumah tangga }\end{array}$} \\
\hline & Key Resources & & Channels & \\
\hline & 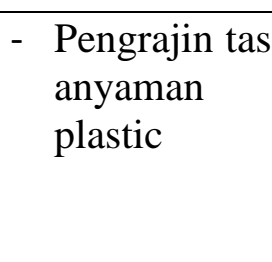 & & $\begin{array}{ll}\text { - } & \text { Social } \\
& \text { (Facebook } \\
& \text { Media } \\
\text { Instagram) } & \text { dan } \\
\text { - } & \text { E-commerce (Shopee ) } \\
\text { - } & \text { Website }\end{array}$ & \\
\hline
\end{tabular}

E-ISSN: 2777-1156 
Fakultas Ekonomi, Universitas Cokroaminoto Yogyakarta

\begin{tabular}{|c|c|}
\hline Cost Structure & Revenue Streams \\
\hline $\begin{array}{ll}\text { - } & \text { Biaya pengambilan produk dari } \\
\text { pengrajin tas anyaman plastic } \\
\text { - } \\
\text { - } \text { Biaya pengemasan } \\
\text { - } & \text { Biaya pemasaran } \\
& \text { Biaya Karyawan }\end{array}$ & Penjualan Tas Anyaman Plastik \\
\hline
\end{tabular}

\section{KESIMPULAN DAN SARAN}

Rencana pengembagan bisnis satu tahun kedepan yang terutama adalah dengan pelebaran pangsa pasar yang dijangkau salah satunya dengan cara Target penjualan tas 50-60 Pcs, Mencari Reseller dari domisili luar pulau, Produk Custom serta Pendaftaran Merek Taesthic.co. Dalam mengembangkan dan meningkatkan penjualan Taesthic.co menggunakan bisnis model canvas karena bekerja sama oleh para pengrajin anyaman plastik dari daerah Ponorogo, mengunggulkan kualitas dan keunikan dari produk anyaman, promosi yang dilakukan menggunakan website, sosial media dan juga e-commerce. Menjaga kelestarian seni kerajinan anyaman yang merupakan salah satu kesenian yang harus di jaga, salah satunya adalah tas anyaman plastik. Seiring berubahnya zaman menjadi modern saat ini tidak banyak yang menggunakan tas anyaman plastik karena dianggap kuno dan kurang bervariasi. Produk lokal juga banyak ditinggalkan karena di nilai tidak berkualitas dan juga tidak bervariasi. Kurangnya peminat tas anyaman plastik mengakibatkan banyak pengrajin yang kehilangan pekerjaan. Maka Taesthic.co hadir untuk membantu para pengrajin dalam memasarkan produk dan memperkenalkan produk local

Sehingga penelitian ini diharapkan setelah merumuskan model bisnis, selanjutnya dirumuskan desain transformasi model bisnis sebagai strategi untuk mengembangkan perusahaan dengan pendekatan yang juga menggunakan business model canvas. Business model canvas tidak hanya dapat digunakan untuk memotret model bisnis perusahaan saat ini, namun juga dapat digunakan sebagai alat untuk memberikan usulan rancangan model bisnis yang baru. Untuk merumuskan desain transformasi model bisnis, digunakan peta empati konsumen (customer empathy map). Peta empati konsumen dibuat untuk menghasilkan model bisnis yang lebih kuat, karena profil pelanggan memandu perancangan proposisi yang

\section{E-ISSN: 2777-1156}




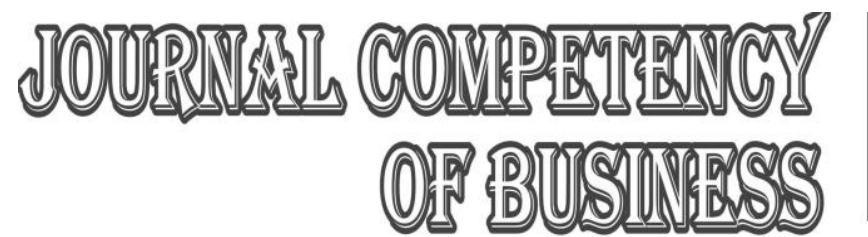

Fakultas Ekonomi, Universitas Cokroaminoto Yogyakarta

lebih baik, cara pendekatan kepada pelanggan yang lebih nyaman, dan berhubungan dengan pelanggan yang sesuai yang pada akhirnya memberikan pengertian yang lebih mendalam tentang bagaimana pelanggan mendapatkan kepuasan terhadap nilai produk/jasa jika dibandingkan dengan harga yang ditawarkan. Pada tahapan ini dilakukan diskusi terfokus antara peneliti dan beberapa konsumen yang pernah mencoba produk perusahaan.

\section{DAFTAR PUSTAKA}

Brunner, Manuel \& Josef Wolfartsberger (2020). Virtual Reality Enriched Business Model Canvas Building Blocks For Enhancing Customer Retention. International Conference on Industry 4.0 and Smart Manufacturing. 10.1016/j.promfg.2020.02.062

Ferranti, Emma J.S \& Anne Jaluzot. (2020). Using The Business Model Canvas To Increase The Impact Of Green Infrastructure Valuation Tools. Urban Forestry \& Urban Greening https://doi.org/10.1016/j.ufug.2020.126776

Gunawan, M. F. (2016). Perancanagan Business Model Canvas Sebagai Alternatif Strategi Bisnis Budidaya Ikan Gurame (Studi Kasus Pada Ukm Mitra Mina Desa Sridadi Kecamatan Kalirejo Lampung Tengah). Dilihat 1 Februari 2021. Retrieved From Http://Digilib.Unila.Ac.Id/21790/20/Skripsi \%20tanpa\%20bab\%20pembahasan.Pdf

Moleong, L.J. (2012). Metodologi Penelitian Kualitatif. Bandung: PT Remaja Rosdakarya

Osterwalder, A. \& Pigneur, Y. (2012). Business Model Generation. Jakarta : PT. Elex Media Komputindo

Wardhanie, A. P. (2017). Buku Ajar Model Bisnis. Surabaya: PT. Revka Petra Media

Biro Pusat Statistik. (2020). Jumlah Penduduk Provinsi DKI Jakarta Menurut Kelompok Umur Dan Jenis Kelamin 2019

https://sumut.bps.go.id/statictable/2020/06/05/1766/jumlah-penduduk-menurutkelompok-umur-dan-jenis-kelamin-2019.html (Diakses 25 Januari 2021).

E-ISSN: 2777-1156

2021. Vol 5. No 1 